\title{
Mixed Anionic/Non-Ionic Collectors in Phosphate Gangue Flotation from Magnetite Fines
}

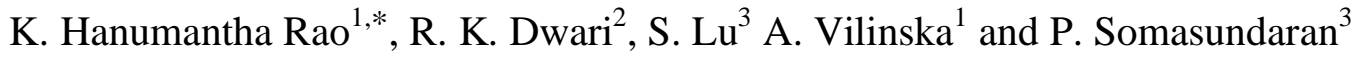 \\ ${ }^{1}$ Division of Mineral Processing and Metallurgy, Department of Chemical Engineering and Geosciences, Luleå \\ University of Technology, SE-971 87 LULEÅ, Sweden \\ ${ }^{2}$ Department of Mineral Processing, Institute of Minerals and Materials Technology, Bhubaneswar 751013, India \\ ${ }^{3}$ Department of Earth and Environmental Engineering, Henry Krumb School of Mines, Columbia University, \\ New York, USA
}

\begin{abstract}
Adsorption, contact angle and flotation of anionic Atrac and non-ionic ethaloxylated nonylphenol surfactant, and their mixture on apatite and magnetite were studied. The effect of calcium ions and sodium silicate on Atrac adsorption was investigated. The effect of Atrac adsorption on the contact angle data of apatite and magnetite in the presence and absence of sodium silicate was also examined. Wettability of solids depends on solids surface free energy and the surface energies of apatite and magnetite powders were calculated from polar and non-polar liquid contact angle data.

A decrease in particle size increased the polar contribution to surface free energy due to unsaturated broken bonds on the surface. Atrac is seen to adsorb equally on apatite and magnetite, and the adsorption increased in the presence of calcium ions. The presence of water glass decreased the Atrac contact angle data on magnetite and also the flotation response demonstrating its role as magnetite depressant in flotation. The presence of non-ionic surfactant enhanced the Atrac flotation of apatite with no flotation of magnetite. Bench-scale flotation tests showed that $50 \%$ of Atrac can be replaced with non-ionic collector without impairing the flotation results. Results also illustrate that the non-ionic adsorbs on apatite in equal amount of Atrac collector signifying 1:1 composition of anionic and non-ionic collector on apatite surface. Nonionic head group sitting in between anionic head groups screens the electrostatic repulsion and forms compact adsorbed layer on apatite surface thereby increasing the hydrophobicity and flotation.
\end{abstract}

Keywords: Flotation, Adsorption, Contact angle, Non-ionic surfactant.

\section{INTRODUCTION}

Generally, the fatty acid flotation of phosphate suffers from its' sensitivity to slimes and ions, the higher temperature requirement and the relatively high consumption [1,2]. The use of surfactant mixtures can have a synergistic advantage over the use of a single surfactant [3]. The selectivity in flotation process increases with decreasing the collector concentration. It is widely known that the non-ionic surfactants co-adsorb with ionics due to alkyl chain-chain interaction. Our earlier studies showed that the presence of non-ionic surfactants increased the adsorption of ionic surfactants due to shielding of electrostatic head-head repulsion by intrusion of nonionics between them and hydrophobic interaction between alkyl chains increases the adsorption of nonionics [4]. The adsorption of ionic/non-ionic surfactant mixtures at solid/liquid interface increases the selectivity without impairing the recovery. The deleterious affects of metal-surfactant precipitation could be minimised with ionic/non-ionic

*Address correspondence to this author at the Division of Mineral Processing, Department of Chemical Engineering and Geosciences, Luleå University of Technology, SE-971 87 LULEÅ, Sweden; Tel: +46 920 491705;

Fax: +46920 97364; E-mail: hanumantha.rao@ltu.se surfactant mixtures due to their hardness tolerance and less sensitivity to a change in solution $\mathrm{pH}$ [5].

The dephosphorization of magnetite ore at LKAB is carried out by floating phosphorous gangue from magnetite fines with a fatty acid based collector. The acceptable level of phosphorous in magnetite fines should be below 0.025 wt $\%$ and it is controlled with the dosage of the collector. Higher dosage of collector is found to contaminate magnetite surfaces and thus becoming difficult to agglomerate magnetite fines because it decreases the strength of the liquid bridges holding particles together [6]. For example, it is more difficult to pelletize iron ore fines that have been rendered hydrophobic in order to aid their recovery by flotation. It requires more volume of liquid water binder to granulate poorly wetting particles thereby increases the energy costs of evaporation in the sintering step.

The aim of this work is to decrease the collector (Atrac) concentration at the LKAB flotation plant to a minimum level with the use of collector modifier (non-ionic surfactants). The results on the effect of Atrac collector and nonionic surfactant, and their mixture on the wettability of apatite and magnetite powders, and the apatite flotation 
response from magnetite fines have been presented and discussed in this paper.

\section{EXPERIMENTAL}

\section{Materials}

Pure natural crystals of fluoroapatite and magnetite were procured from Gregory, Bottley \& Lloyd, London. The crystals were broken into small pieces and dry-ground in an agate mortar. The product was wet-sieved and a size fractions of i) $-300+150 \mu \mathrm{m}$, ii) $-150+38 \mu \mathrm{m}$ and iii) $-38 \mu \mathrm{m}$ were collected. The BET specific surface area of the samples was determined. The contact angle measurements were conducted using all the size fractions and for Hallimond flotation tests, the $-150+38 \mu \mathrm{m}$ size fraction is employed. The $-38 \mu \mathrm{m}$ size fraction is used in the adsorption studies. The material for batch scale flotation tests was the same that is being fed to the Kiruna concentrator. About $40 \mathrm{~kg}$ materials were collected from the feed line to the flotation circuit at the plant and it was filtered, dried and sampled to 2 $\mathrm{kg}$ batches.

All flotation chemicals, Atrac, water glass and MIBC that are being used at Kiruna concentrator were obtained. The non-ionic ethoxylated surfactant with 6 EO groups was supplied by Akzo Nobel AB. Reagent grade chemicals of $\mathrm{CaSO}_{4} \cdot 2 \mathrm{H}_{2} \mathrm{O}, \mathrm{KNO}_{3}, \mathrm{NaHCO}_{3}, \mathrm{MgCl}_{2} \cdot 6 \mathrm{H}_{2} \mathrm{O}$ and $\mathrm{NaCl}$ were used to prepare synthetic water with the same ionic composition as that of LKAB concentrator process water and this synthetic water was used for batch flotation tests.

Water used in all the adsorption experiments was triple distilled, with a specific conductivity of less than $2.5 \mathrm{~S}$ $\mathrm{cm}^{-1}$ and was tested for the absence of organics using surface tension measurements. The ionic concentrations in the simulated water were $600 \mathrm{mg} / \mathrm{SO}_{4}{ }^{2-}, 20 \mathrm{mg} / \mathrm{N} \mathrm{NO}_{3}{ }^{-}, 300$ $\mathrm{mg} / \mathrm{l} \mathrm{Cl}^{-}, 30 \mathrm{mg} / \mathrm{l} \mathrm{Mg}^{2+}, 250.3 \mathrm{mg} / \mathrm{l} \mathrm{Ca}^{2+}, 55.9 \mathrm{mg} / \mathrm{l} \mathrm{K}^{+}, 195$ $\mathrm{mg} / \mathrm{l} \mathrm{Na}{ }^{+}$and $2.47 \mathrm{mg} / 1 \mathrm{HCO}_{3}^{-}$. Water $\mathrm{pH}$ was adjusted to 8.1 with $\mathrm{NaOH}$ to resemble process water conditions.

\section{Contact Angle Measurements}

The Washburn method was used to determine the liquid contact angle on mineral powders. Well characterised water, formamide and 1-bromonaphthalene test liquids with known energy parameters were used for contact angle measurements and surface energy calculations. The surface energy is an important parameter in wet granulation of iron ore fines. The Kruss K100 tensiometer was used, which incorporates the Washburn technique for determining the contact angle and surface energy of a solid powder by sorption measurements.

The Washburn equation defines the liquid flow through a capillary and it is given as

$$
\frac{m^{2}}{t}=\frac{c \cdot \rho^{2} \cdot \gamma_{L} \cdot \cos \theta}{\eta}
$$

where, $m$ is the mass of the penetrating liquid, $\gamma_{L}$ is the surface tension of the liquid, $\rho$ is the density of measuring liquid, $\eta$ is the viscosity of liquid, $t$ is the time, $\theta$ is the contact angle and $c$ is a material constant which is dependent on the porous structure of the packed solid particles. In the above equation, $\gamma_{L}, \rho$ and $\eta$ are the constants. The mass of penetrating liquid which rises into the porous packed bed can be monitored as a function of time and can be plotted $\mathrm{m}^{2}$ versus $t$.
The contact angle of the liquid on the solid, $\theta$, and the solid material constant, $c$, are the two unknowns in the equation. If a Washburn experiment is performed with a liquid which is known to have contact angle of $\theta=0^{\circ}(\cos \theta=1)$ on the solid, then the solid material constant is the only remaining unknown in the equation and can thus be determined. Therefore, the constant $c$ is determined with an extra measurement before the first real measurement by using a non-polar liquid like n-hexane with low surface tension $\left(18.4 \mathrm{~mJ} / \mathrm{m}^{2}\right)$ which wets the surface completely.

\section{Adsorption Measurements}

Adsorption experiments were conducted in capped $20 \mathrm{ml}$ vials. Solid samples of 2 grams were mixed with $10 \mathrm{ml}$ of triple distilled water for 2 hours at room temperature. The $\mathrm{pH}$ was adjusted as desired and then $10 \mathrm{ml}$ of the surfactant solution was added, and the samples were equilibrated further for 16 hours with $\mathrm{pH}$ adjustment. The samples were centrifuged for 30 minutes at $3000 \mathrm{rpm}$ and the clear supernatant was pipetted out for analysis. Adsorption density was then calculated based upon the surfactant depletion in the solution. In the case of magnetite, the supernatant after centrifugation was yellowish, suggesting the presence of fine solid particles, therefore, the samples were filtered using 200-nm membranes to remove the suspended particles. After filtration, the supernatant became colorless. The residual concentration of Atrac was determined by measuring the total organic carbon (TOC) using a Shimadzu Total Organic Carbon Analyzer.

\section{Hallimond Flotation Tests}

The flotation tests of single minerals of apatite and magnetite in the presence of Atrac collector, Atrac/non-ionic surfactant mixture and in the presence and absence of water glass were conducted in a Hallimond tube with $1 \mathrm{~g}$ of mineral and $100 \mathrm{ml}$ of collector solution. The mineral suspension was always conditioned first with water glass before conditioning with collector. When the tests were performed in the presence of a mixture of non-ionic surfactant and Atrac collector, the mineral was initially conditioned with collector and then with the non-ionic surfactant. The conditioning time was about $15 \mathrm{~min}$ and flotation time was $1 \mathrm{~min}$ at an air flow rate of $200 \mathrm{ml} \mathrm{min}^{-1}$. After flotation, the products were allowed to air-dry overnight.

\section{Bench Scale Flotation Tests}

Sampled material of $1 \frac{1}{2} \mathrm{Kg}$ was used for each batch flotation test in an Agitair laboratory flotation machine. The pulp level in the cell was usually adjusted to $2 \mathrm{~cm}$ below the weir, corresponding to a pulp density of approximately $40 \%$ solids by weight. The pulp was conditioned for $10 \mathrm{~min}$ in the presence of $500 \mathrm{~g} / \mathrm{t}$ water glass followed by $5 \mathrm{~min}$ conditioning with predetermined dosage of Atrac collector. Flotation was performed at a constant air-flow rate in all cases after the introduction of $3 \mu \mathrm{l} \mathrm{MIBC}$ frother. The froth products were collected at 1, 2, 4 and 7 min flotation times. All flotation tests were conducted at $\mathrm{pH} 8.5$ and water glass dosage was also kept constant at $500 \mathrm{~g} / \mathrm{t}$. When non-ionic collector was used together with Atrac, the pulp was first conditioned with Atrac for $5 \mathrm{~min}$ followed by $5 \mathrm{~min}$ conditioning with non-ionic collector. Tests were conducted in the presence of Atrac and non-ionic collectors alone and at equal proportions 
of Atrac and non-ionic collectors together. In addition, different proportions of Atrac and non-ionic collectors were also used. Froth products at different time intervals containing apatite gangue and magnetite material remaining in the cell are filtered, dried, weighed and chemically analysed. The analysis was done at the LKAB laboratory.

\section{RESULTS AND DISCUSSION}

\section{Contact Angle Studies}

Wettability of solids is important not only for flotation but also agglomeration concerning the interaction of solids with water. The low surface energy of solids causes water repellency resulting in a weak attraction between the solid and the liquid phase. High energy surfaces are often exhibit low water contact angle while the surfaces covered by films of adsorbed organic molecules lead to non-polar sites on the solid surface and display low surface energy and higher contact angle. Since the wettability is related to the solids-water contact angle, which in turn depends on the solids surface energy, the surface energies of apatite and magnetite at different size fractions are comprehensively examined.

The sorption curves of test liquids for all the size fractions of apatite and magnetite, and water contacted angle on solids treated at different concentrations of Atrac and in the presence of water glass have been recorded. An illustration of these results, the sorption curves of test liquids on magnetite solids, water sorption of solids treated at different concentrations of Atrac and water sorption of solids conditioned at different concentrations of water glass in the presence of Atrac are presented in Figs. (1, 2 and $\mathbf{3}$ ) respectively.

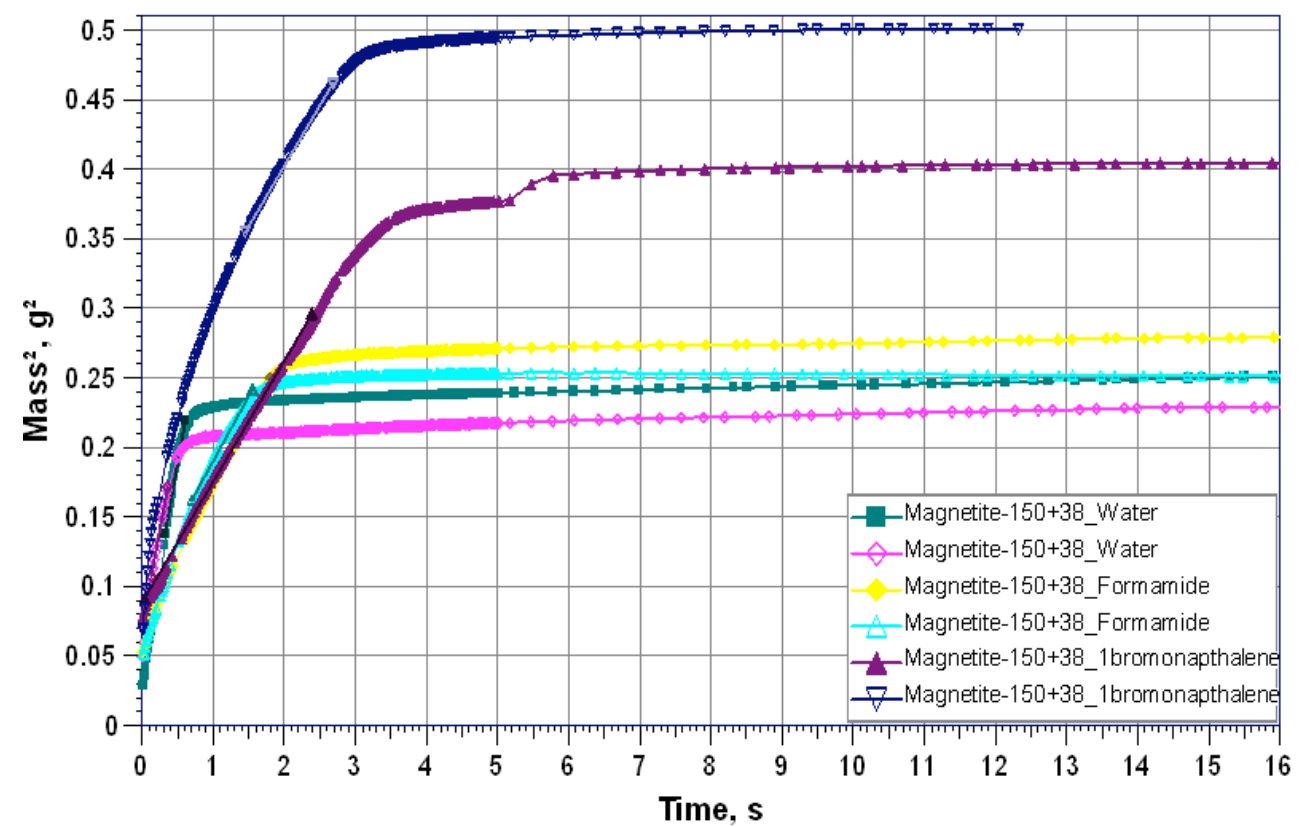

Fig. (1). Sorption curves of test liquids on magnetite for the measurement of contact angle.

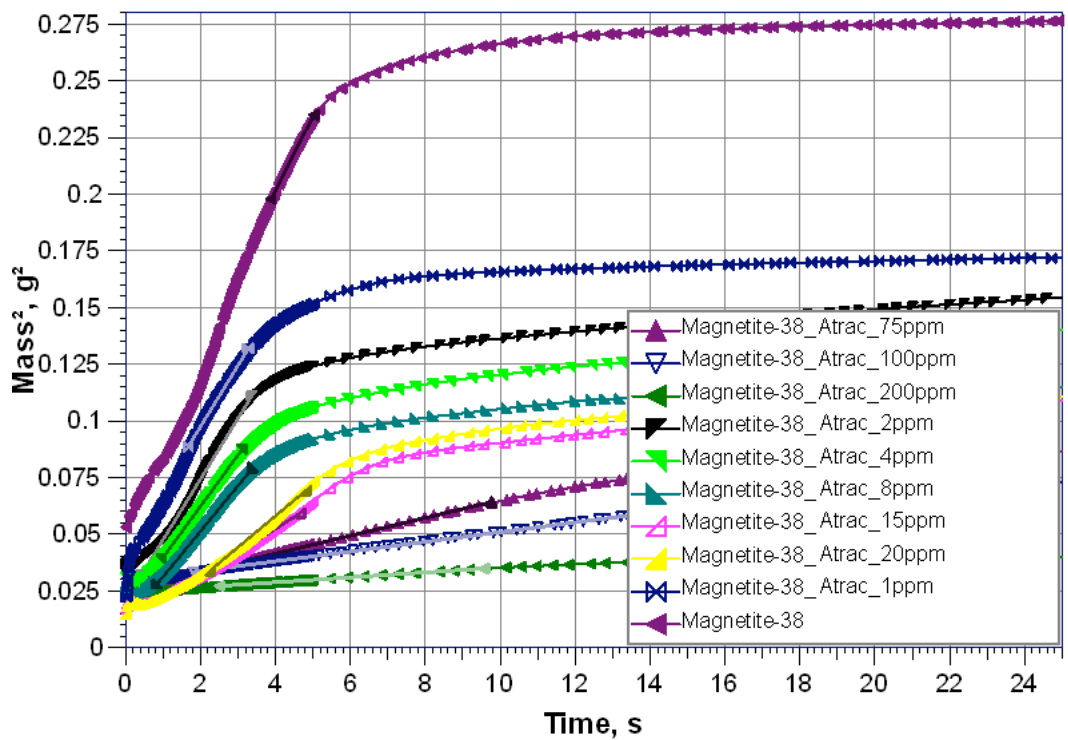

Fig. (2). Effect of Atrac concentration on water sorption of - $38 \mu \mathrm{m}$ magnetite particles. 


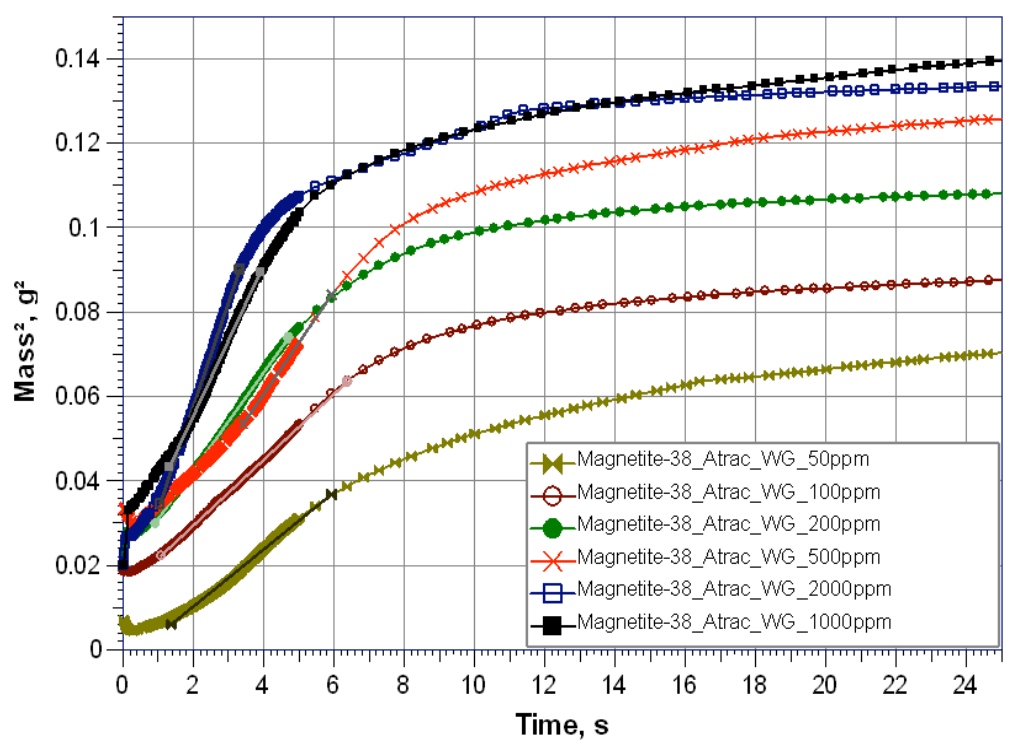

Fig. (3). Effect of sodium silicate (WG) concentration on water sorption of -38 $\mu \mathrm{m}$ magnetite particles in the presence of 100 ppm Atrac collector.

The capillary constant and the contact angle of test liquids on different size fractions of apatite and magnetite have been calculated from the sorption curves using Washburn equation. The results for apatite and magnetite are shown in Tables $\mathbf{1}$ and $\mathbf{2}$ respectively. The capillary constant is seen to decrease with decreasing particle size since the powder bed will become more compact with a decrease in particle size. From the contact angle data, the surface energy of apatite and magnetite powders has been calculated. The total surface energy, dispersive and polar components of surface energy, and the polar component divided into acid-base components have been presented in Tables $\mathbf{3}$ and $\mathbf{4}$ for magnetite.

In general, the water contact angle on apatite and magnetite is seen to decrease with decreasing particle size, which is obvious due to increased polarity of the surfaces caused by many broken bonds on the surface structure (Tables $\mathbf{3}$ and $\mathbf{4}$ ). This is also reflected in the surface energy data of both the minerals where the surface energy increased with decreasing particle size, in particular the polar contribution to the surface energy. The dispersion component differs only slightly, which points to a small contribution of dipole-dipole and induced-dipole-dipole intermolecular interactions to the apatite or magnetite surface free energy. Surface free energy of apatite and magnetite was consistently between 55 and 65 $\mathrm{mN} / \mathrm{m}$ with relative contribution of the dispersion and polar components to free energy of approximately $1 / 3$ and $2 / 3$ respectively. The polar part divided into acid and base parts shows that the increased surface energy with decreasing particle size is mostly due to the increase in base part of the surface energy illustrating that the oxygen sites are most exposed on the surface.

The sorption curves of water on Atrac coated apatite and magnetite solids showed that the slope $\left(\mathrm{m}^{2} / \mathrm{t}\right)$ of magnetite sorption curves decreases with increasing Atrac concentra-

Table 1. Capillary Constant and Contact Angle of Test Liquids on Apatite Solids

\begin{tabular}{|c|c|c|c|}
\hline Mineral & Capillary Constant, $\mathrm{C}, \mathrm{cm}^{5}$ & Test Liquids & Contact Angle $^{\circ}$ \\
\hline \multirow{3}{*}{$\begin{array}{l}\text { Apatite } \\
-425+150 \mu \mathrm{m}\end{array}$} & \multirow[t]{3}{*}{$6.1712 \mathrm{E}-5$} & n-hexane & 0 \\
\hline & & Formamide & $11.85 \pm 0.85$ \\
\hline & & I-Bromonapthalene & $11 \pm 1$ \\
\hline \multirow{2}{*}{$\begin{array}{l}\text { Apatite } \\
-150+38 \mu \mathrm{m}\end{array}$} & \multirow{2}{*}{$2.9418 \mathrm{E}-5$} & Formamide & $8.10 \pm 1.50$ \\
\hline & & I-Bromonaphthalene & $4.4 \pm 0.40$ \\
\hline \multirow{2}{*}{$\begin{array}{l}\text { Apatite } \\
-38 \mu \mathrm{m}\end{array}$} & \multirow[t]{2}{*}{$3.7376 \mathrm{E}-6$} & n-hexane & 0 \\
\hline & & Water & $55.3 \pm 5.70$ \\
\hline
\end{tabular}


Table 2. Capillary Constant and Contact Angle of Test Liquids on Magnetite Solids

\begin{tabular}{|c|c|c|c|}
\hline Sample Name & Capillary Constant, $\mathrm{C}, \mathrm{cm}^{5}$ & Test Liquids & Contact Angle $^{\circ}$ \\
\hline \multirow{4}{*}{$\begin{array}{l}\text { Magnetite } \\
-300+150 \mu \mathrm{m}\end{array}$} & \multirow[t]{4}{*}{$6.88305 \mathrm{E}-5$} & n-hexane & 0 \\
\hline & & Water & $43.33 \pm 2.7$ \\
\hline & & Formamide & $41.45 \pm 1.4$ \\
\hline & & I-Bromonapthalene & 4.8 \\
\hline \multirow{4}{*}{$\begin{array}{l}\text { Magnetite } \\
-150+38 \mu \mathrm{m}\end{array}$} & \multirow[t]{4}{*}{$4.5621 \mathrm{E}-5$} & n-hexane & 0 \\
\hline & & Water & $32.25 \pm 0.55$ \\
\hline & & Formamide & $7.25 \pm 0.52$ \\
\hline & & I-Bromonaphthalene & $4.0 \pm 0.40$ \\
\hline \multirow{4}{*}{$\begin{array}{l}\text { Magnetite } \\
-38 \mu \mathrm{m}\end{array}$} & \multirow[t]{4}{*}{$4.5052 \mathrm{E}-6$} & n-hexane & 0 \\
\hline & & Water & $6.0 \pm 1.40$ \\
\hline & & Formamide & $4.52 \pm 1.48$ \\
\hline & & I-Bromonaphthalene & $2.45 \pm 1.25$ \\
\hline
\end{tabular}

Table 3. Surface Energy of Magnetite Using Fowkes Equation

\begin{tabular}{|l|l|l|l|l|}
\hline Mineral & Test Liquids & Surface free energy, $\mathbf{m N} / \mathbf{m}$ & Disperse part, $\mathbf{m N} / \mathbf{m}$ & Polar part, $\mathbf{m N} / \mathbf{m}$ \\
\hline \hline \multirow{2}{*}{$\begin{array}{l}\text { Magnetite } \\
-300+150 \mu \mathrm{m}\end{array}$} & Water/1-Bromonapthalene & 64.04 & 43.84 & 20.20 \\
\cline { 2 - 5 } & Formamide/1-Bromonapthalene & 48.48 & 43.84 & 4.64 \\
\hline \multirow{2}{*}{$\begin{array}{l}\text { Magnetite } \\
-150+38 \mu \mathrm{m}\end{array}$} & Water/1-Bromonapthalene & 69.65 & 43.89 & 25.76 \\
\cline { 2 - 6 } & Formamide/1-Bromonapthalene & 58.33 & 43.89 & 14.44 \\
\hline \multirow{2}{*}{$\begin{array}{l}\text { Magnetite } \\
-38 \mu \mathrm{m}\end{array}$} & Water/1-Bromonapthalene & 77.96 & 43.96 & 34.00 \\
\cline { 2 - 5 } & Formamide/1-Bromonapthalene & 58.28 & 43.96 & 14.32 \\
\hline
\end{tabular}

Table 4. Surface Energy of Magnetite Using Van-Oss Acid-Base Approach with Water, Formamide and 1-Bromonapthalene Contact Angles

\begin{tabular}{|l|l|l|l|l|l|}
\hline Mineral & Surface Free Energy, $\mathbf{~ m N} / \mathbf{m}$ & Disperse Part, $\mathbf{m N} / \mathbf{m}$ & Polar Part, $\mathbf{m N} / \mathbf{m}$ & Acid Part, $\mathbf{m N} / \mathbf{m}$ & Base Part, $\mathbf{m N} / \mathbf{m}$ \\
\hline \hline $\begin{array}{l}\text { Magnetite } \\
-300+150 \mu \mathrm{m}\end{array}$ & 43.4 & 44.2 & -0.8 & 0.0 & 40.5 \\
\hline $\begin{array}{l}\text { Magnetite } \\
-150+38 \mu \mathrm{m}\end{array}$ & 57.9 & 44.2 & 13.7 & 1.3 & 36.2 \\
\hline $\begin{array}{l}\text { Magnetite } \\
-38 \mu \mathrm{m}\end{array}$ & 56.5 & 44.3 & 12.2 & 0.7 & 54.7 \\
\hline
\end{tabular}

tion (Fig. 2), which reflects the low rate of water sorption due to surface hydrophobic character rendered by the collector adsorption. Likewise the water sorption curves by apatite conditioned at different concentrations of Atrac showed a decreased rate of water sorption with increased Atrac adsorption on apatite. The water contact angles on apatite and magnetite as a function of Atrac concentration determined from the sorption curves are shown in Fig. (4).

The contact angle on pure apatite surface is higher than on magnetite (Fig. 4). This suggests that the magnetite surface has more wettability character than apatite. The contact angle on apatite increases with increasing Atrac concentration and attained $90^{\circ}$ at $25 \mathrm{ppm}$. With further increase in
Atrac concentration the contact angle on apatite remain constant. In the case of magnetite, contact angle of $90^{\circ}$ reaches at a higher Atrac concentration of $100 \mathrm{ppm}$. These results unquestionably show the adsorption of Atrac on apatite and magnetite with a little difference of higher adsorption on apatite at lower concentrations than on magnetite. The contact angle results are comparable to the adsorption results presented in the next section.

Water sorption curves have been registered for the apatite and magnetite solids treated with increasing concentration of water glass at a constant Atrac concentration of $100 \mathrm{ppm}$. The solids are conditioned first with water glass before Atrac addition. The sorption curves on magnetite are shown in Fig. 


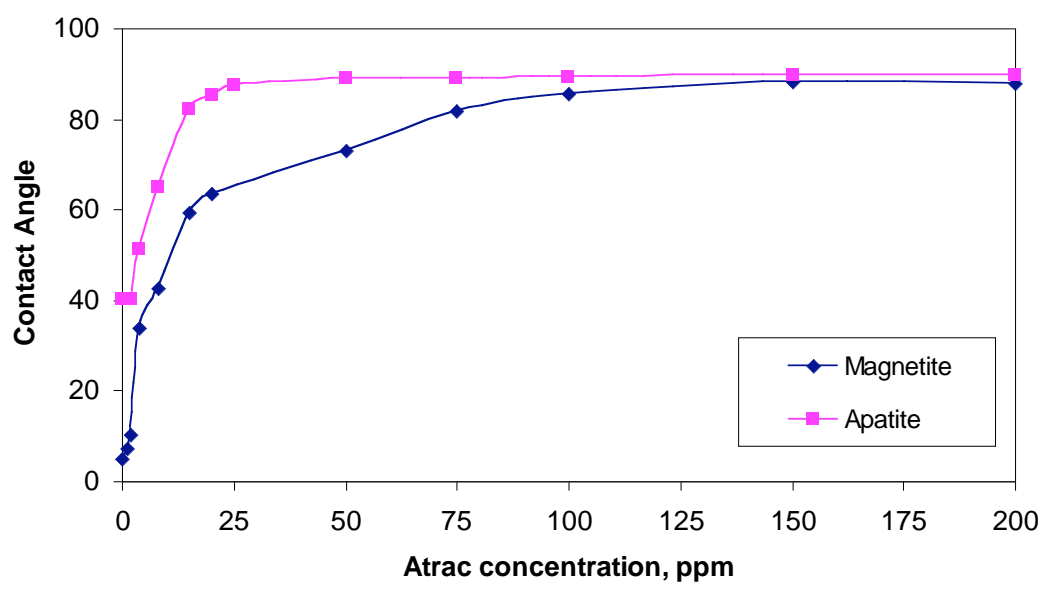

Fig. (4). Effect of Atrac concentration on water contact angle of $-38 \mu \mathrm{m}$ magnetite and apatite particles.

(3). It can be seen from these curves that the rate of water sorption increases with increasing water glass concentration. In the case of apatite, the rate of water sorption was found to be low smaller than that of magnetite and nearly the same until $500 \mathrm{ppm}$ water glass concentration. Water glass is seen to effect magnetite wettability even at low concentrations and therefore, it functions as magnetite depression in apatite flotation from magnetite fines besides its flotation pulp dispersion role.

The effect of water glass concentration on apatite and magnetite contact angles is shown in Fig. (5). The apatite contact angle of about $90^{\circ}$ in the presence of 100 ppm Atrac is unaffected until $500 \mathrm{ppm}$ water glass concentration, above which concentration, it decreases. In the case of magnetite, the contact angles are seen to decrease continuously with increasing water glass concentration. These results show the beneficial effect of water glass in apatite flotation but at concentrations below 500 ppm. Higher water glass concentration leads to increased wettability of both the minerals.

\section{Adsorption Studies}

The adsorption of Atrac on apatite and magnetite was determined using the depletion technique in the absence of calcium and in the presence of $140 \mathrm{ppm}$ calcium. The adsorption isotherms of Atrac on apatite and magnetite are shown in Figs. (6 and 7) respectively. The adsorption on apatite increases with the residual concentration and reaches a near plateau value above $40 \mathrm{ppm}$ equilibrium concentration. In case of magnetite, the plateau range was not reached in the concentration range tested. Atrac is a modified fatty acid and contains two carboxylic groups with a alkyl chain containing up to 23 carbon atoms [7]. Assuming Atrac has a normal molecular weight $(200 \sim 500)$, the maximum concentration is below $1 \mathrm{mM}$, which is probably lower than the CMC. It is interesting to see that the maximum adsorption is about $1 \times 10^{-3} \mathrm{~g} / \mathrm{m}^{2}$, which is roughly $3 \times 10^{-6} \mathrm{~mol} / \mathrm{m}^{2}$ if the molecular weight is about $300 \mathrm{~g} / \mathrm{t}$. Allowing a molecular coverage area of Atrac about 50 to $60 \AA^{2}$ having two carboxylic groups, this adsorption density is close to monolayer.

The presence of calcium increases the adsorption density in both cases. In the $\mathrm{pH}$ range tested $(\mathrm{pH} 8.5 \pm 0.3)$, apatite is negatively charged. The increases can be again attributed to the shielding of electrostatic repulsion between the substrate and the surfactant molecules. Since Atrac is also seen to adsorb on magnetite comparable to the adsorption on apatite, the calcium species are the main reason for Atrac adsorption on magnetite suggested earlier is doubtful [6]. The higher adsorption on apatite than magnetite is found to be rather marginal and Atrac collector is seen to adsorb on apatite and magnetite similarly with or without calcium ions. However,

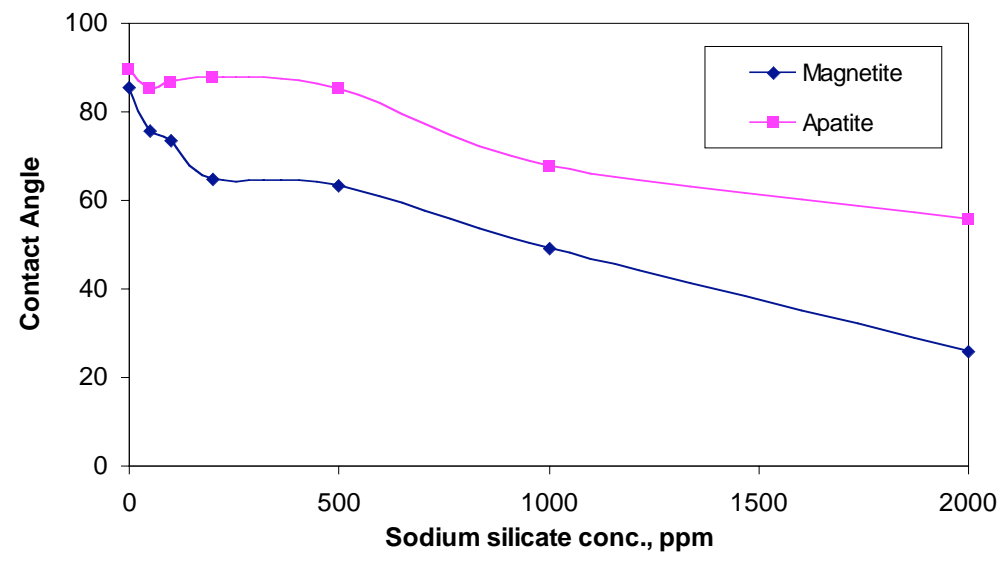

Fig. (5). Effect of sodium silicate concentration on water contact angle of $-38 \mu \mathrm{m}$ apatite and magnetite particle in the presence of 100 ppm atrac collector. 
Atrac collector exhibits higher affinity to apatite surface compared to magnetite surface since it adsorbs on apatite at lower concentrations than on magnetite.

The adsorption isotherms of Atrac on apatite and magnetite in the presence of water glass are shown in Figs. (8 and 9) respectively. It can be seen that the presence of sodium silicate does not affect the adsorption amount on apatite significantly with $0.5 \mathrm{mM}$ and $1 \mathrm{mM} \mathrm{Na} \mathrm{SiO}_{3}$. Interestingly, the adsorption of Atrac on magnetite was significantly reduced in the presence of $1 \mathrm{mM}$ sodium silicate, while the presence of $0.5 \mathrm{mM}$ sodium silicate doesn't alter the adsorption much.

\section{Hallimond Flotation Studies}

The flotation response of apatite and magnetite in the presence and absence of calcium ions as a function of Atrac collector concentration is shown in Fig. (10). Complete flota-

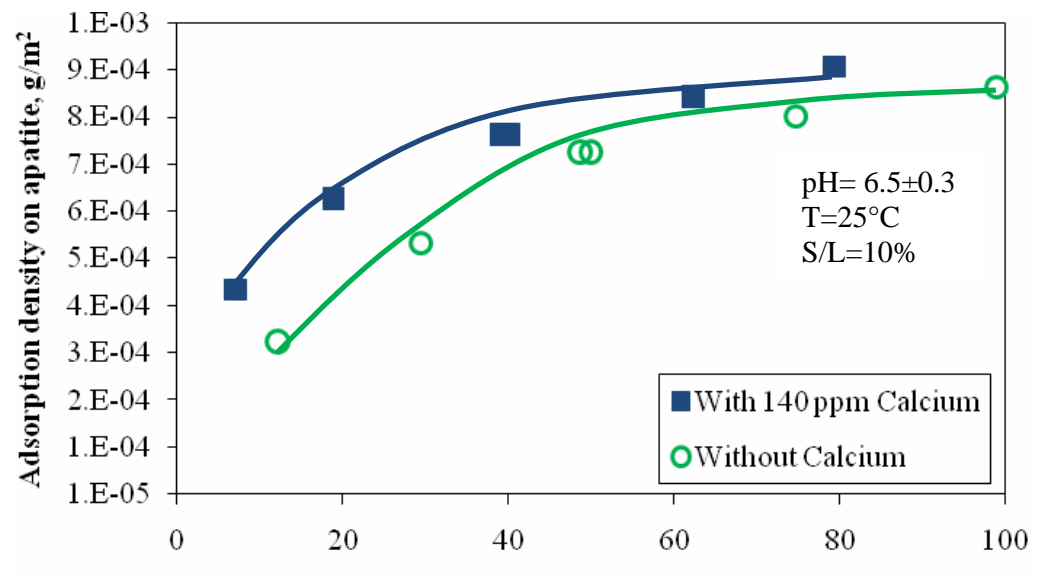

Atrac residual concentration, ppm

Fig. (6). Adsorption of Atrac on apatite as a function of equilibrium concentration.

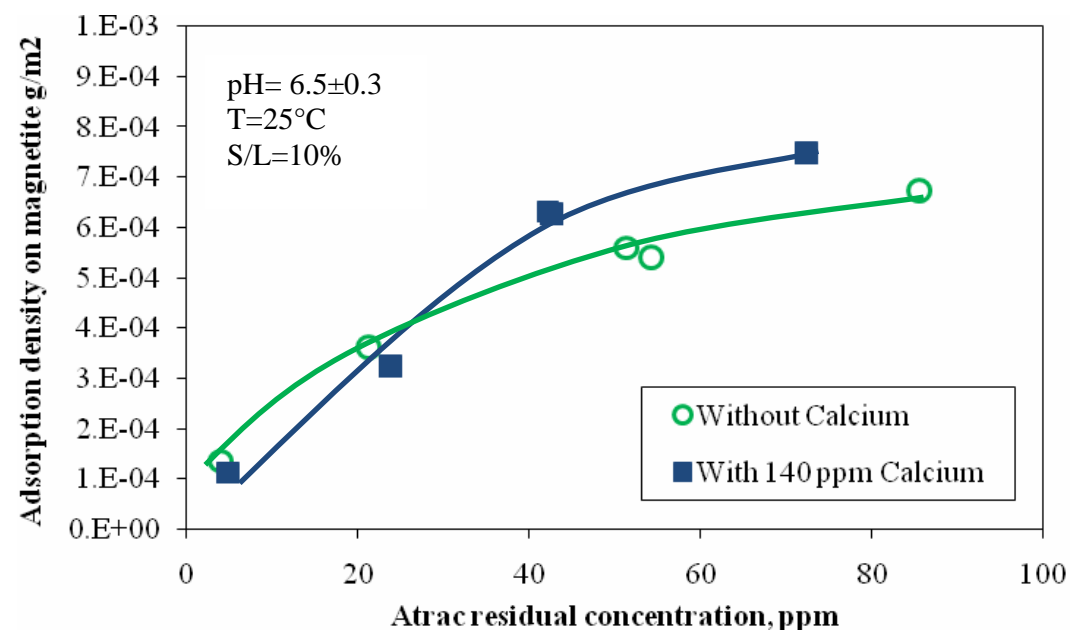

Fig. (7). Adsorption of Atrac on magnetite as a function of equilibrium concentration.

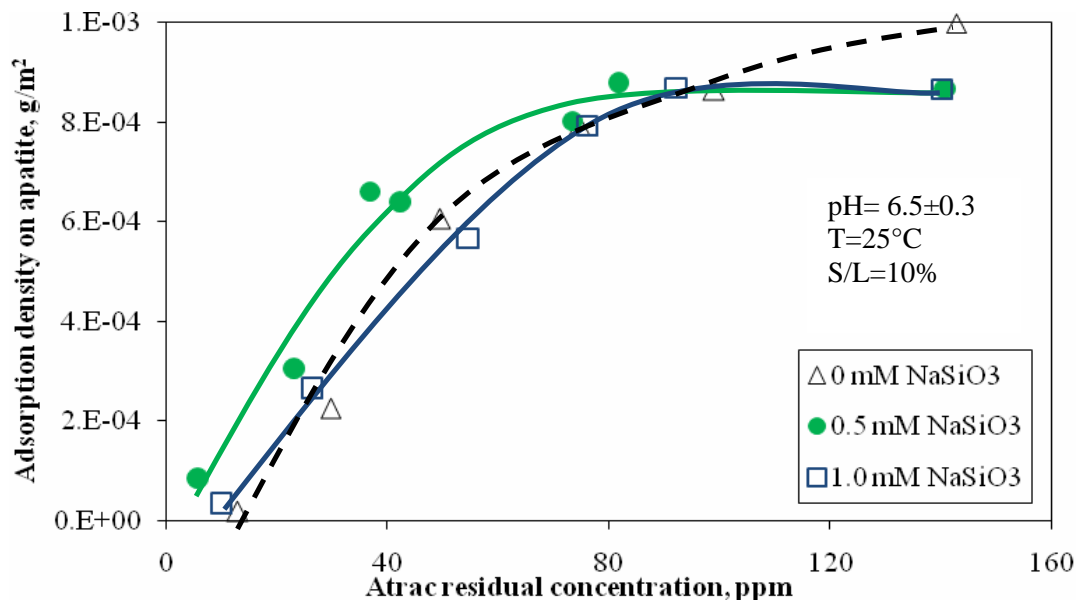

Fig. (8). Adsorption of Atrac on apatite in the presence of water glass (WG). 


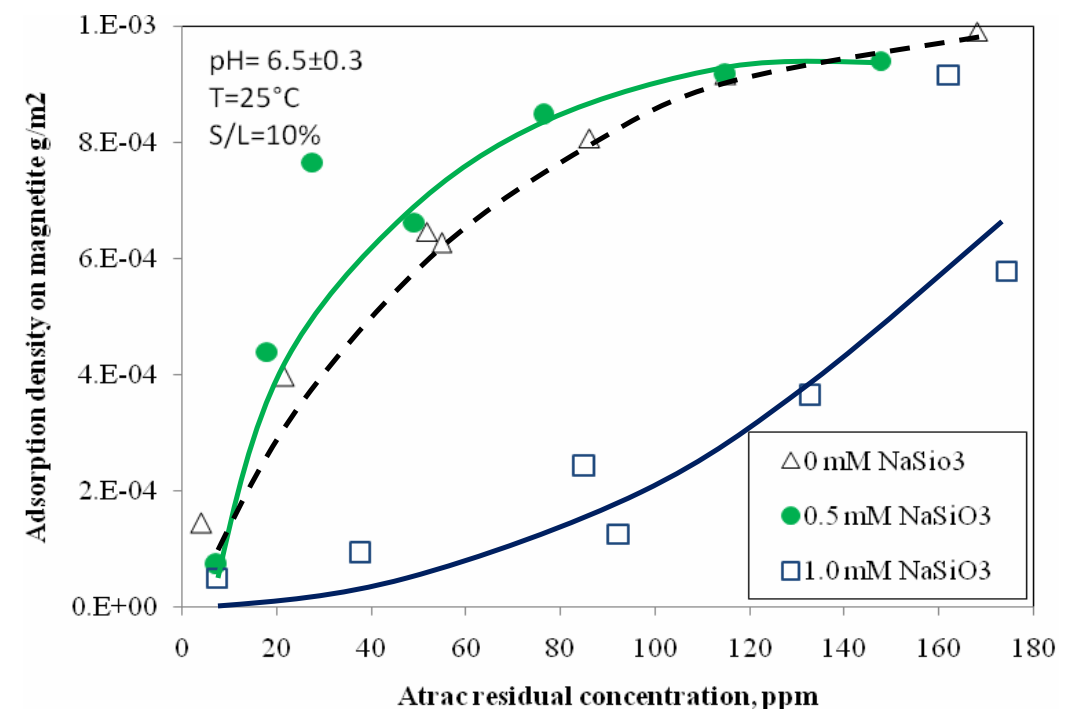

Fig. (9). Adsorption isotherms of Atrac on magnetite in the presence of water glass (WG).

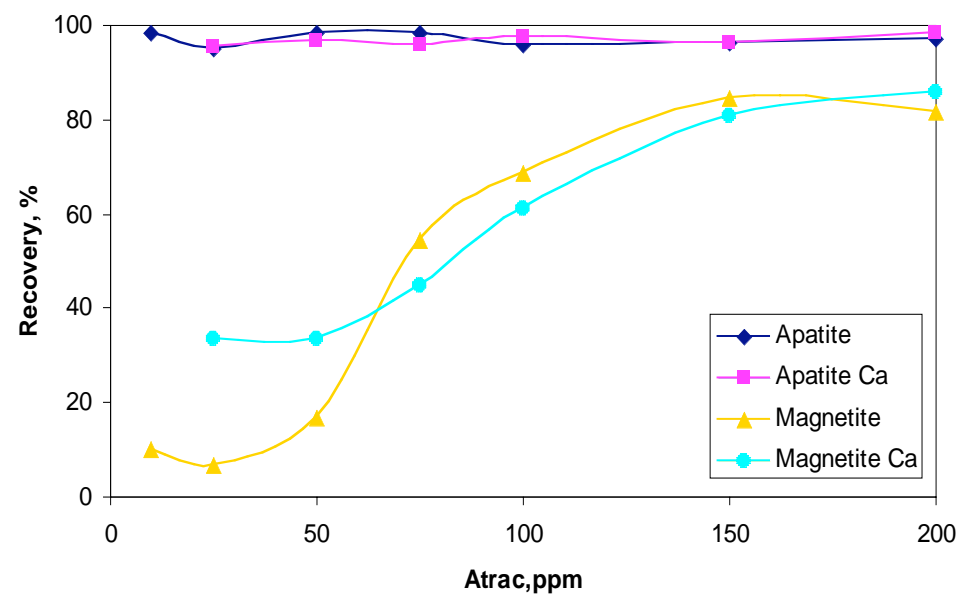

Fig. (10). Atrac flotation of apatite and magnetite in the presence and absence of calcium ions at $8.5 \mathrm{pH}$.

tion apatite is observed at a very low Atrac concentration where the magnetite recovery is about $10 \%$. However, magnetite recovery increased to $40 \%$ in the presence of calcium ions. Above $50 \mathrm{ppm}$ of Atrac concentration, magnetite recovery is seen to increase. The flotation behavior is not reflected with adsorption results where the adsorption of Atrac on magnetite found to be slightly higher than apatite.

The influence of water glass concentration on apatite and magnetite flotation is displayed in Fig. (11). There is no effect of water glass on apatite flotation until $250 \mathrm{ppm}$; and above which this concentration, the recovery decreases. Magnetite flotation is depressed at a very low concentration of 50 to $100 \mathrm{ppm}$ water glass, where an initial 60\% recovery decreased to about $20 \%$ recovery. These flotation results agree the contact angle data presented above in Fig. (4).

Fig. (12) shows the flotation recoveries of apatite and magnetite in the presence of ethoxylated (6 EO groups) nonylphenol non-ionic surfactant. Apatite is seen to float marginally with about $20-30 \%$ recovery while the magnetite flotation is meager. The increase in non-ionic surfactant concentration didn't yield higher recovery suggesting its low or no interaction with the minerals.
The influence of non-ionic surfactant on Atrac flotation of apatite and magnetite is presented in Fig. (13). A very low concentration of $2 \mathrm{ppm}$ Atrac is used where $30 \%$ apatite is floated and there is no flotation of magnetite. The presence of non-ionic surfactant increased the apatite flotation from 30 to $80 \%$ while the magnetite flotation remains zero. This is a significant result of the beneficial effect of nonionic surfactant on Atrac flotation of apatite. At a bare minimum concentration of Atrac, the apatite will be adsorbed by Atrac but with a very low surface coverage imparting some degree of hydrophobicity. The addition of non-ionic surfactant increased the hydrophobicity of apatite by its adsorption through lateral tail-tail (hydrophobic) interaction. Since there is no Atrac on magnetite surface at such a low concentration, the non-ionic surfactant cannot be adsorbed.

\section{Bench Scale Flotation Studies}

Since the aim of these tests were to evaluate non-ionic surfactant as Atrac collector modifier for phosphorous flotation, the phosphorous content in the final magnetite concentrate is considered as the main quality index in the flotation results given below. The water contact angle on magnetite 


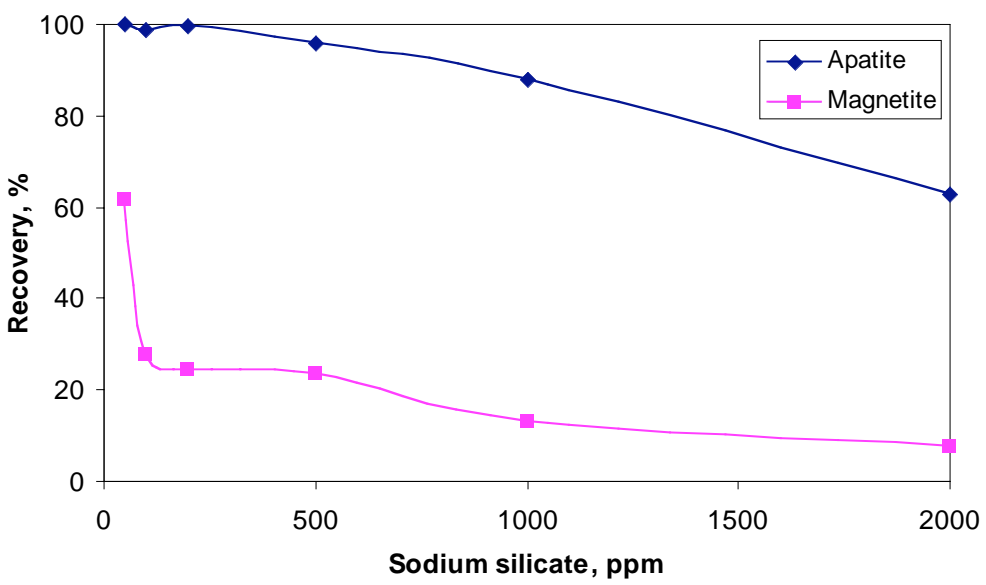

Fig. (11). Effect of water glass on Atrac flotation of apatite and magnetite at $\mathrm{pH}$ of 8.5 and $100 \mathrm{ppm}$ Atrac.

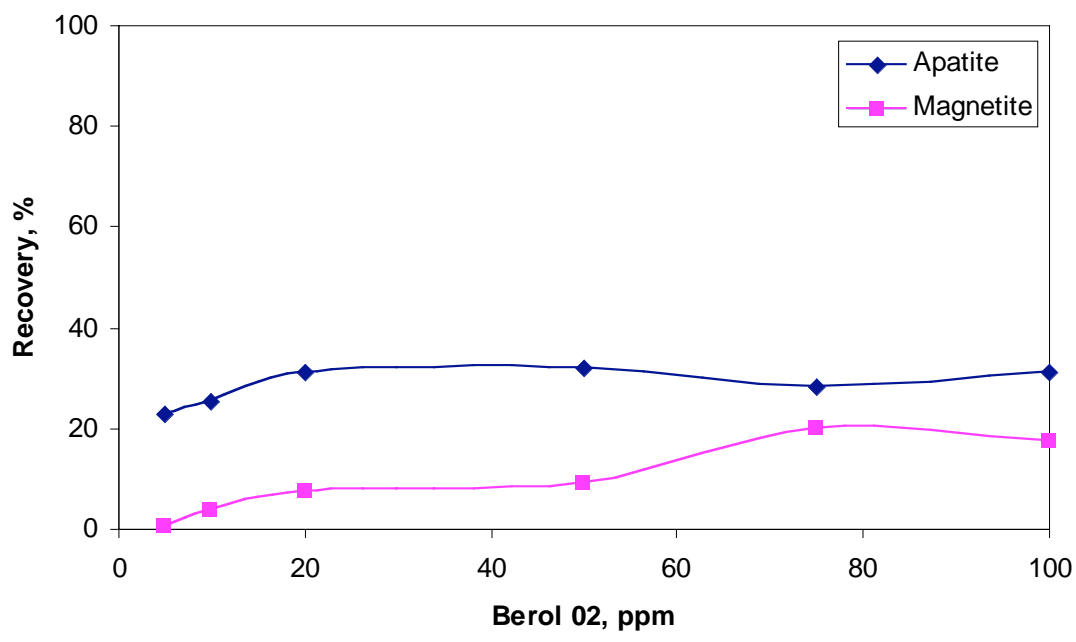

Fig. (12). Non-ionic collector flotation of apatite and magnetite at $8.5 \mathrm{pH}$.

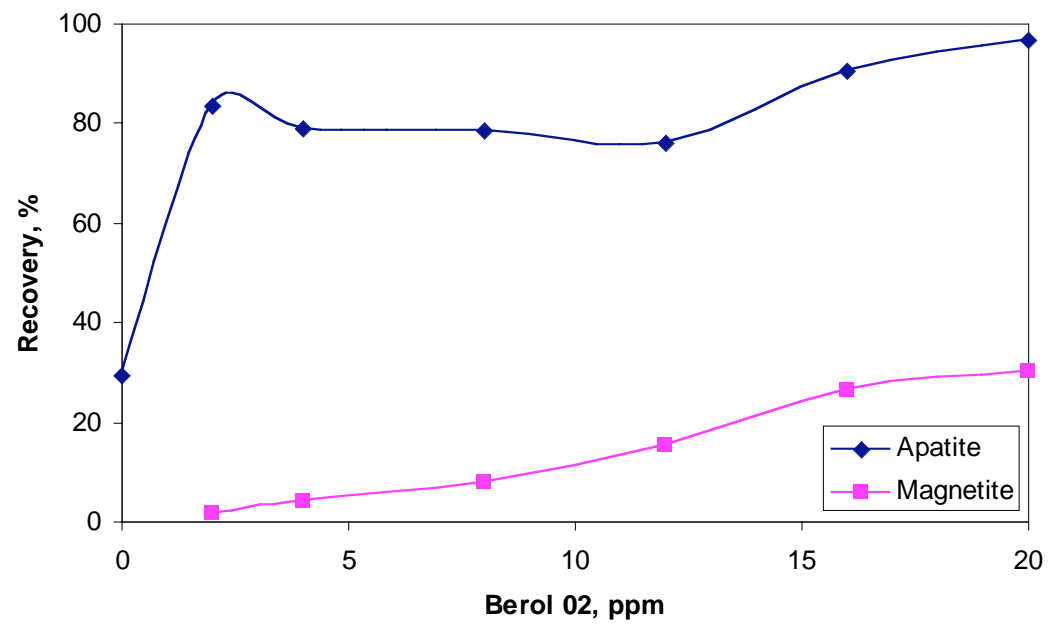

Fig. (13). Influence of non-ionic collector concentration on Atrac flotation of apatite and magnetite at $8.5 \mathrm{pH}$ and $2 \mathrm{ppm} \mathrm{Atrac.}$

concentrates is given to distinguish the extent of their surface hydrophobicity/hydrophilicity character.

Flotation test results of magnetite concentrate with increasing dosage of Atrac and non-ionic collectors are presented in Tables 5 and 6 respectively. Phosphorous in the feed contains about $0.063 \%$ and it was floated with increasing dosage of Atrac but not floated with non-ionic. The phosphorous is reduced to $0.012 \%$ in magnetite concentrate at $50 \mathrm{~g} / \mathrm{t}$ of Atrac and these results corroborate our earlier batch flotation test results [8,9]. Hallimond flotation tests 
with pure minerals showed no flotation of apatite with nonionic and it was the case with the flotation feed material at LKAB. Water contact angle on pure magnetite powder for the $-150+38$ and $-38 \mu \mathrm{m}$ size fractions were determined to be $33^{\circ}$ and $6^{\mathrm{O}}$ respectively. The material prior to flotation had $44^{\mathrm{O}}$ contact angle and it is increased to about $64^{\mathrm{O}}$ after flotation on magnetite concentrate, irrespective of whether Atrac or non-ionic is used in the flotation tests.

The effect of non-ionic collector in combination with Atrac collector is investigated with equal amounts of nonionic and Atrac, and with increasing total amount of collector dosage. The flotation results are shown in Table 7. Phosphorous in magnetite concentrate is seen to decrease continuously with increasing total dosage of collector. Interestingly, the phosphorous is reduced to $0.010 \%$ at $50 \mathrm{~g} / \mathrm{t}$ total mixed collectors dosage which is better or coincides to $0.012 \%$ phosphorous reduction when $50 \mathrm{~g} / \mathrm{t}$ Atrac is used alone. It was also the case at $20 \mathrm{~g} / \mathrm{t}$ of mixed collector or 20 $\mathrm{g} / \mathrm{t}$ of Atrac alone where phosphorous in magnetite concentrate is $0.028 \%$. These results undoubtedly illustrate that $50 \%$ of Atrac collector can be replaced with non-ionic col- lector without impairing flotation results. Since there is no flotation of apatite with non-ionic but performing as apatite collector in the presence of Atrac, it is clear that the nonionic is adsorbing on apatite surface due to tail-tail hydrophobic interaction of the collectors. There is no big variation in the water contact angles on magnetite concentrates with increasing total collector dosage. The values are marginally lower compared to the values when Atrac collector is used alone at the same dosage.

Hallimond flotation results showed that the non-ionic is effective at equal amount of Atrac collector and no influence exceeding Atrac dosage. Phosphorous content in magnetite concentrates at different proportions of mixed collector is reduced to the level equalling to the total dosage of mixed collector at 1:1 proportion when non-ionic amount is less than Atrac or Atrac dosage alone. When non-ionic amount exceeds Atrac amount, there is no further decrease in phosphorous beyond the level of Atrac dosage. The results in Table $\mathbf{8}$ suggest that non-ionic cannot be adsorbed on apatite more than the amount of Atrac.

Table 5. Flotation Results as a Function of Atrac Dosage

\begin{tabular}{|l|l|l|l|l|}
\hline \multirow{2}{*}{ Test no. } & \multirow{2}{*}{ Atrac $(\mathrm{g} / \mathrm{t})$} & \multicolumn{3}{|c|}{ Magnetite Product } \\
\cline { 3 - 6 } & & $\mathbf{P} \%$ & Fe-Recovery \% & Contact Angle $^{\text {o }}$ \\
\hline \hline 1 & 10 & 0.043 & 99.5 & 42.72 \\
\hline 2 & 20 & 0.028 & 99.3 & 65.93 \\
\hline 3 & 35 & 0.015 & 98.9 & 64.99 \\
\hline 4 & 50 & 0.012 & 98.6 & 63.32 \\
\hline
\end{tabular}

Table 6. Flotation Results at Two Dosages of Non-Ionic Collector

\begin{tabular}{|l|l|l|l|l|}
\hline \multirow{2}{*}{ Test no. } & Non-Ionic $(\mathrm{g} / \mathrm{t})$ & \multicolumn{3}{|c|}{ Magnetite Product } \\
\cline { 3 - 6 } & & $\mathbf{P} \%$ & Fe-Recovery \% & Contact Angle $^{\text { }}$ \\
\hline \hline 6 & 20 & 0.059 & 99.6 & 46.55 \\
\hline 5 & 50 & 0.059 & 98.6 & 63.86 \\
\hline
\end{tabular}

Table 7. Flotation Results at Equal Amounts of Atrac and Non-Ionic Collectors

\begin{tabular}{|c|c|c|c|c|c|}
\hline \multirow[t]{2}{*}{ Test no. } & \multirow[t]{2}{*}{$\operatorname{Atrac}(g / t)$} & \multirow[t]{2}{*}{ Non-Ionic (g/t) } & \multicolumn{3}{|c|}{ Magnetite Product } \\
\hline & & & $\mathbf{P} \%$ & Fe-Recovery \% & Contact Angle ${ }^{\circ}$ \\
\hline 8 & 5.0 & 5.0 & 0.054 & 99.8 & 50.01 \\
\hline 14 & 7.7 & 7.7 & 0.034 & 99.5 & 51.75 \\
\hline 7 & 10.0 & 10.0 & 0.028 & 99.2 & 58.09 \\
\hline 12 & 13.7 & 13.7 & 0.028 & 99.2 & 51.48 \\
\hline 9 & 15.0 & 15.0 & 0.025 & 99.2 & 59.39 \\
\hline 10 & 20.0 & 20.0 & 0.016 & 99.0 & 61.22 \\
\hline 11 & 25.0 & 25.0 & 0.010 & 98.0 & 61.70 \\
\hline
\end{tabular}


Table 8. Flotation Results at Different Ratios of Atrac and Non-Ionic Collectors

\begin{tabular}{|c|c|c|c|c|c|}
\hline \multirow[t]{2}{*}{ Test no. } & \multirow[t]{2}{*}{$\operatorname{Atrac}(g / t)$} & \multirow[t]{2}{*}{ Non-Ionic $(g / t)$} & \multirow[t]{2}{*}{ Atrac + Non- Ionic $(g / t)(1: 1)$} & \multicolumn{2}{|c|}{ Magnetite Product } \\
\hline & & & & $\mathbf{P} \%$ & Contact Angle $^{o}$ \\
\hline 17 & 5.0 & $13.7(+5.0)$ & 10.0 & 0.050 & 55.00 \\
\hline 14 & 7.7 & $7.7(+7.7)$ & 15.4 & 0.034 & 51.75 \\
\hline 15 & 7.7 & $20.0(+7.7)$ & 15.4 & 0.033 & 51.66 \\
\hline 18 & 13.7 & $5.0(+5.0)$ & 18.7 & 0.036 & 50.31 \\
\hline 19 & 13.7 & $13.7(+13.7)$ & 27.4 & 0.030 & 51.80 \\
\hline 12 & 13.7 & $13.7(+13.7)$ & 27.4 & 0.028 & 51.48 \\
\hline 22 & 13.7 & $22.7(+13.7)$ & 27.4 & 0.024 & 61.67 \\
\hline 13 & 20.0 & $7.7(+7.7)$ & 27.7 & 0.023 & 61.06 \\
\hline 20 & 22.7 & 13.7 & 36.4 & 0.013 & 57.73 \\
\hline 16 & 20.0 & 20.0 & 40.0 & 0.018 & 59.65 \\
\hline
\end{tabular}

\section{CONCLUSIONS}

The following conclusions are drawn from the adsorption, contact angle and flotation experiments carried out with single anionic Atrac and non-ionic ethaoxylated nonylphenol studies:

1. Surface free energies found to be consistent with increasing energy as the particle size decreases. Based on the surface energies magnetite particles exhibit more wettability character than apatite.

2. Anionic Atrac adsorbs on apatite and magnetite comparably with a little higher adsorption on apatite and the presence of calcium ions increased the adsorption to some extent in both the cases.

3. Adsorption and contact angle data of apatite and magnetite in the presence of Atrac and water glass are consistent with the flotation responses.

4. Atrac flotation response of apatite increased in the presence of non-ionic surfactant with no effect on magnetite flotation. At a very low level of Atrac concentration, it adsorbs on apatite but not on magnetite. The presence of non-ionic surfactant at this condition increases the hydrophobicity of apatite by its adsorption through lateral alkyl chain-chain interaction. Since there is no adsorption of Atrac on magnetite surface at a lower concentration, the non-ionic surfactant has no influence on magnetite surface.

5. Bench scale flotation results showed that $50 \%$ of Atrac can be replaced with non-ionic collector without impairing the flotation results.

6. Water contact angles on magnetite concentrates with Atrac and non-ionic collectors showed marginally lower values than Atrac alone at the same amount of dosage.

\section{ACKNOWLEDGEMENTS}

The financial support from Hjalmar Lundbohm Research Centre (HLRC) and Centre for Advanced Mining and Metallurgy (CAMM) is gratefully acknowledged. One of the authors, $\mathrm{KH}$ Rao, also acknowledges Wenner Gren Foundation for a sabbatical grant of his work at the Department of Earth and Environmental Engineering, Columbia University, USA.

\section{REFERENCES}

[1] R. Houot, "Beneficiation of phosphatic ores through flotation: review", Int. J. Miner. Process., Vol. 9, pp.353-384, 1982.

[2] H. Sis and S. Chander, S, "Reagents used in the flotation of phosphate ores: a critical review", Miner. Eng., Vol. 16, pp. 577-585, 2003.

[3] J.F. Scamehorn, "An overview of phenomena involving surfactant mixtures", In: Phenomena in Mixed Surfactant Systems, J. F. Scamehorn, Ed: ACS Symposium Series 311, Am Chem Soc: Washington DC, 1986, pp 1-27.

[4] K. Hanumantha Rao and K.S.E. Forssberg, "Mixed collector systems in flotation", Int. J. Miner. Process., Vol. 51, pp. 67-79, 1997.

[5] P. Somasundaran, L. Xiao and T. V. Vasudevan, "Separation of salttype minerals by flotation using a structurally modified collectors", In: Proceedings XVII Int. Miner. Process Congr., Bergakademie: Freiberg, Vol. 2, 1991, pp. 379-391.

[6] K. Hanumantha Rao, P.O. Samskog, and K.S.E. Forssberg, "Pulp chemistry of the flotation of phosphate gangue from magnetite fines", Trans. Inst. Miner Metall., Sec C, Vol. 99, pp. 147-156, 1990.

[7] P. Swiatowski, A. Andersen and A. Askenbom, "Process for the froth flotation of oxide and salt type minerals and composition", US patent no. 5130037,7 pp., 1992.

[8] F. Su, K. Hanumantha Rao, K.S.E. Forssberg and P.O. Samskog, "The influence of pulp temperature on the kinetics of apatite flotation from magnetite fines", Int. J. Miner. Process., Vol. 54, pp. 131-145, 1998 .

[9] K. Hanumantha Rao, F. Su and K.S.E. Forssberg, "Flotation kinetics of apatite from magnetite", In Beneficiation of Phosphates: Advances in Research and Practice, P Zhang, H. El-Shall, and R. Wiegel, Eds: The Society for Mining, Metallurgy and Exploration, Inc: Colorado, 1999, pp. 103-125. 